\title{
The problem of professional burnout in stress management
}

\author{
Natalia Makasheva ${ }^{1}$, Julia Makasheva ${ }^{2, a}$, Anna Gromova ${ }^{3}$, Sergey Ishtunov ${ }^{4}$, and Boris Burykhin ${ }^{5}$ \\ 1,2,3.4 Tomsk Polytechnic University, 634050 Lenin Avenue, 30, Tomsk, Russia \\ ${ }^{5}$ Tomsk State University, 634050 Lenin Avenue, 36, Tomsk, Russia
}

\begin{abstract}
The problem of professional burnout is extremely relevant in current stress management. By its nature, professional burnout is a unique type of stress syndrome that is characterized by emotional exhaustion. It leads to loss of energy and interest in one's job. A burnout could be the result of such syndromes as - burnout and boreout. It could emerge as the reaction of the organism to the high working intensity and stress working conditions or due to the boredom and absence of the sphere for professional realization. Both syndromes negatively influence the professional activity and require serious research and an adequate approach to the study. Studies have been conducted in the higher educational environment and among production employees. The studies were conducted with the application of the existing tests for revealing the "boreout" and "burnout" syndromes. Studies have shown that the syndrome "burnout" is common among workers with free working regulations, whose work requires greater independence, initiative and responsibility. According to the results of the study, the employees who are more free in the performance of their professional duties (teachers, managers) are less subjected to the boreout syndrome. For the prevention and control of professional burnout company management needs to apply the achievements of stress management.
\end{abstract}

\section{Introduction}

In staff management, the stress issues arising in the sphere of the employment have become more and more important in recent years. A crisis wave, an unfavorable socio-economic situation in the country, an alarming international and political situation of recent years result in the feeling of depression, suppression and insecurity. The complexity and variability of the modern world requires from the employee a permanent readiness to the changes, the ability to adapt to new conditions and to meet the growing requirements in the sphere of professional activity. Such factors often lead to stresses which are the reflection of body's reaction to the negative impact of the environment.

In addition, the features of economic development at the current stage could be seen in the rise of a labor creative component share, which in its turn implies a greater independence and initiative of employees. But such activity comprises stressful features.

Psychologists say that under such conditions, the average level of people's stress exceeds their physiological abilities. This negatively influences human's health, psycho-emotional state and, finally, reduces vital functions.

Thus, in the modern world, stress is becoming a large social problem which is of great importance for the society in whole and for the individual organizations. The relevance of this issue confirms the development of the specific management area - stress management, the task of which is to study and predict stress as well as to manage the staff on the basis of modern technologies of anti-stress employee protection.

\section{Materials and methods}

One of the understudied issues of stress management is the problem of professional burnout. This term specifies a range of adverse events associated with the professional activities: a sense of emotional and physical exhaustion, indifference to work, pessimism, the lack of professional development desire, unwillingness to improve the working results, etc. [1]

Professional burnout may be reflected in the forms of "burnout" or "boreout" syndromes.

The "burnout" syndrome was first distinguished and described in America in the early 70s of the last century by the example of doctors' professional activity. This syndrome revealed itself as a response of the organism to the constant emotional and interpersonal stresses at work. Currently, the scientists define the phenomenon of "burnout" by three following distinctive features [2]:

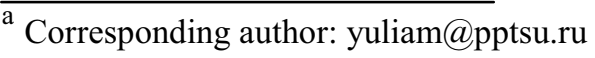


- the presence of burnout signs, which is characterized by a feeling of exhaustion, hypertension and depletion of the emotional resources;

- loss of personality, that is, such a state when there is a feeling of social isolation, which is reflected in a cynical attitude towards work and colleagues;

- decreasing of personal achievements, feeling of incompetence at work and failure.

Table 1 describes the most common characteristic features of professional burnout signs.

Table 1. Job burnout symptoms

\begin{tabular}{|c|c|}
\hline $\begin{array}{l}\text { Psycho-physical } \\
\text { symptoms }\end{array}$ & $\begin{array}{l}\text { The feeling of constant fatigue, even in } \\
\text { the morning, immediately after waking } \\
\text { up (chronic fatigue symptom). } \\
\text { The sense of emotional and physical } \\
\text { exhaustion. } \\
\text { General asthenia (weakness, decreasing } \\
\text { of activity and energy). } \\
\text { Reduced susceptibility and reaction due } \\
\text { to the changes in the external } \\
\text { environment (a lack of curiosity response } \\
\text { to the new factor or a lack of fear } \\
\text { response to a dangerous situation). } \\
\text { Constant somnolence, drowsiness and } \\
\text { desire to sleep all day long. }\end{array}$ \\
\hline $\begin{array}{l}\text { Social and } \\
\text { psychological } \\
\text { symptoms }\end{array}$ & $\begin{array}{l}\text { Indifference, boredom, inactivity and } \\
\text { depression, a feeling of suppression. } \\
\text { Increased irritability to minor events. } \\
\text { Failures of communication, withdrawal. } \\
\text { Feeling of guilt, resentment, shame. } \\
\text { The feeling of unconscious trouble and } \\
\text { high anxiety (the feeling that "something } \\
\text { is wrong, not like as it should be"). } \\
\text { Feeling of hyper-responsibility and } \\
\text { constant fear that "it will not work" or "I } \\
\text { can not do it." } \\
\text { The total negative attitude to life and } \\
\text { career prospects ("no matter how hard } \\
\text { you try, it still does not work"). }\end{array}$ \\
\hline $\begin{array}{l}\text { Behavioural } \\
\text { symptoms }\end{array}$ & $\begin{array}{l}\text { The feeling that the work is getting } \\
\text { harder and harder, and that it is } \\
\text { becoming very difficult to cope with the } \\
\text { task. } \\
\text { An employee significantly changes his or } \\
\text { her working schedule (increases or } \\
\text { reduces the time of work). } \\
\text { Constantly, without any urgent necessity, } \\
\text { a person takes the work to carry out } \\
\text { home, but does not do it. } \\
\text { Reduction of enthusiasm for work, } \\
\text { indifference to the results. } \\
\text { Failure of fulfilling important priority } \\
\text { tasks. } \\
\text { Most of the working time is spent on } \\
\text { little apprehensive or unconscious } \\
\text { execution of automatic and elementary } \\
\text { actions. } \\
\text { Distancing from colleagues, increasing } \\
\text { of inadequate criticality. }\end{array}$ \\
\hline
\end{tabular}

Currently, similar symptoms are observed in people of different occupations [3-7]. Initially emerged as a medical problem, burnout syndrome is considered today as an urgent problem of stress management, as professional burnout negatively affects the performance of professional activities.

The concept of "boreout syndrome" has appeared recently, in 2007, in the work of Swiss economists Philippe Rothlin and Peter Werder "Diagnose boreout". The researchers of this syndrome have noted that the reason for its emergence is not worker's laziness but the nature of the work itself: the monotony and inaction. Such work may also lead to person's professional burnout. An employee in this case starts to feel chronic fatigue and boredom of inaction, sustained loss of interest to work against the background of feeling uselessness and futility of her or his work. Constant search for ways to kill the time at work is accompanied by the twinges of conscience and fear of exposure. All this is slowly beginning to press upon the employee. Being in such condition for a long period of time can lead to nervous exhaustion. This, of course, negatively affects the general condition of the person and the professional activity.

In both cases, the sense of depression that occurs due to stress or the state of boredom, results in the employee's emotional state of dissatisfaction. Both syndromes adversely affect the performance of professional duties and require serious study as well as the development of competent solutions for their prevention and elimination.

\section{Research and results}

Studies have been conducted in the higher educational environment and among production employees. In both cases, the two groups of workers were identified with different terms and conditions of employment. One group consisted of workers for whom the performance of their professional duties requires to be at the workplace during the whole working day. The other group included employees whose activities are less regulated and they are less tied to the workplace. The studies were conducted with the application of the existing tests for revealing the "boreout" and "burnout" syndromes $[8,9]$.

Researches in Tomsk Polytechnic University were conducted among groups of the teaching staff, the support staff and the faculty members of the University. A survey of teaching and support staff has shown that $32 \%$ of the respondents are subjected to the professional burnout caused by burnout syndrome and $37 \%$ are subjected to the professional burnout caused by boreout syndrome. Thus, for the professional burnout of employees involved in the working process during the whole working day, these factors are of equal importance.

Among faculty members of the University staff these results differ. $46 \%$ of the respondents were subjected to the professional burnout caused by burnout syndrome, while only $21 \%$ were subjected to the professional burnout caused by boreout syndrome. According to these results, the teaching staff is more subjected to the professional burnout caused by burnout syndrome than 
to the burnout caused by boreout syndrome, in other word the syndrome of inaction.

Also a study was conducted among the petroleum industry workers. The testees were divided into a group of workers from the petroleum transportation department and a group of employees from the company's administration. The activity of the first group of workers is more monotonous and tied to the workplace. The employees of the second group are more free in their professional activities. The results have showed that $44 \%$ of testees from the first group are subjected to the professional burnout caused by burnout syndrome, and $56 \%$ are subjected to the professional burnout caused by boreout syndrome. Thus, for the production workers, as well as for the university staff, who have a fairly monotonous work and who are more tied to the workplace, both professional burnout syndromes are relatively equal.

Among the company's administration, 59\% of the respondents are subjected to the professional burnout caused by burnout syndrome and $21 \%$ are subjected to the professional burnout caused by boreout syndrome. These data show that the administration staff is more subjected to the professional burnout caused by burnout syndrome.

Professional burnout can result from various factors. Table 2 describes what factors result in job burnout.

Table 2. Job burnout factors

\begin{tabular}{|c|c|}
\hline Factors & Description \\
\hline The lack of control & $\begin{array}{l}\text { An inability to influence decisions such } \\
\text { as your schedule, assignments or } \\
\text { workload could affect your job and could } \\
\text { lead to job burnout. The same is true for } \\
\text { a lack of the resources you need to do } \\
\text { your work. }\end{array}$ \\
\hline $\begin{array}{l}\text { Unclear job } \\
\text { expectations }\end{array}$ & $\begin{array}{l}\text { If you're unclear about the degree of } \\
\text { authority you have or what your } \\
\text { supervisor or others expect from you, } \\
\text { you're not likely to feel comfortable at } \\
\text { work }\end{array}$ \\
\hline $\begin{array}{l}\text { Dysfunctional } \\
\text { workplace } \\
\text { dynamics }\end{array}$ & $\begin{array}{l}\text { Perhaps you work with an office bully, } \\
\text { or you feel undermined by colleagues or } \\
\text { your boss micromanages your work. This } \\
\text { can contribute to job stress }\end{array}$ \\
\hline $\begin{array}{l}\text { Mismatch in } \\
\text { values }\end{array}$ & $\begin{array}{l}\text { If your values differ from the way your } \\
\text { employer does business or addresses } \\
\text { grievances, the mismatch can eventually } \\
\text { take a toll }\end{array}$ \\
\hline Poor job fit & $\begin{array}{l}\text { If your job does not fit your interests and } \\
\text { skills, it might become increasingly } \\
\text { stressful over time }\end{array}$ \\
\hline $\begin{array}{l}\text { Extremes of } \\
\text { activity }\end{array}$ & $\begin{array}{l}\text { When a job is monotonous or chaotic, } \\
\text { you need constant energy to remain } \\
\text { focused, which can lead to fatigue and } \\
\text { job burnout }\end{array}$ \\
\hline $\begin{array}{c}\text { The lack of social } \\
\text { support }\end{array}$ & $\begin{array}{l}\text { If you feel isolated at work and in your } \\
\text { personal life, you might feel more } \\
\text { stressed }\end{array}$ \\
\hline $\begin{array}{l}\text { Work-life } \\
\text { imbalance }\end{array}$ & $\begin{array}{l}\text { If your work takes up so much of your } \\
\text { time and effort that you do not have } \\
\text { energy to spend time with your family } \\
\text { and friends, you might burn out quickly }\end{array}$ \\
\hline
\end{tabular}

A number of research into the antecedents of burnout syndrome has been steadily growing [3 - 7]. Studies have shown that, while there are many causes of burnout, people are more likely to experience it when they work in a physically or emotionally demanding role, or when their efforts at work do not produce the results that they expected. In addition, studies show that people who experience burnout early in their career often find it easier to recover than people who go through it later in life.

\section{Conclusion}

The feeling of burnout can occur on the grounds of emotional tension, frequent stresses at work, high responsibility, the need to make decisions in the shortest possible time and with a high degree of risk. The impact of these factors finds its reflection in burnout syndrome. Studies have shown that this syndrome is common among workers with free working regulations, whose work requires greater independence, initiative and responsibility. This occupation is very expressive and emotionally active. Thus it may lead to over-exhaustion and depletion of human emotional resources. The results of the research in the group of the faculty members of Tomsk Polytechnic University and the petroleum company administration have confirmed the prevalence of burnout syndrome in the professional occupation of such type.

The reasons of the professional burnout caused by boreout syndrome are different. It may be a lack of interesting occupations, monotonous work with a repeated action, weak supervision and low salaries and benefits, all these lead to the permanent inaction and chronic boredom at work. Under the influence of such factors, professional personal burning may also occur. The symptoms involve the loss of interest to work, passivity and unwillingness to take the initiative, fatigue and irrelevance. According to the results of the study, the employees who are more free in the performance of their professional duties (teachers, managers) are less subjected to the boreout syndrome.

We can highlight several categories of workers that make the main professional burnout risk group (figure 1). They are specialists whose daily routine lies in communication with people: teachers, doctors and nurses, managers working with clients, journalists, recruiters, PR managers. Constant communication with a great number of different people leads to the emotional stress which results in professional burnout.

The risk group also includes workers who solve various complex tasks in everyday and operational work being constantly subjected to timeframes pressure. These, above all, are the chiefs of different levels. At the same time, the higher the level of responsibility, the greater the possibility of burnout.

The high probability of risk exists for people who are perfectionists. The desire always and everywhere to achieve the best results requires considerable efforts, which the body could hardly withstand. 
There is also a special type of people who are introverts. Such workers do not show negative emotions in public. Internal tension caused by stress, negative emotions, unfavorable working atmosphere can accumulate and be reflected as burnout or boreout syndromes.

A lot of depends on the person herself/himself in overcoming the burnout problem. First of all, if there are signs of burnout, the symptoms should be analyzed as well as the reasons should be determined. These reasons could be divided into external and internal. Internal reasons often require the interference of specialists doctors, psychologists. Perhaps a person just needs to relax, make a break, distract from usual or annoying things, take a vacation, pay more attention to family, friends, hobbies, sports and cultural events.

External reasons also often depend on the individual's choice. They are disliking of job, dissatisfaction with the colleagues or the chief, a mismatch between the range of duties and the individual moral attitudes and values, disappointment in the profession because it failed the expectations, uncertainty about the competence and the importance of realized work. The presence of such reasons requires more drastic measures from the employee. This may be a job changing, additional training or retraining - that is learning something new or choosing the profession which will bring satisfaction.

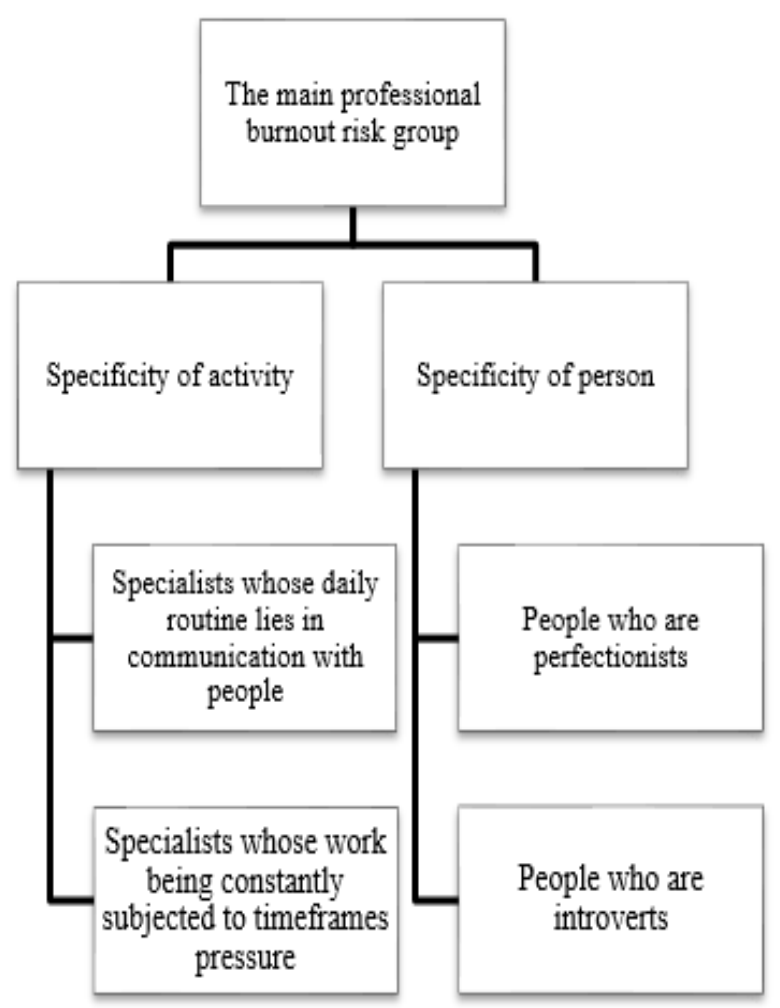

Fig. 1. The main professional burnout risk group

Professional burnout is a costly issue with multiple negative impacts for the company.

Company management should take into account the impact of negative factors on the professional burnout problem [10]. Thus, a strict system of punishment without or with the weak incentive system, an unfair system of motivation, a lack of objective job estimation, unreal demands to employees as well as unreasonably tight deadlines for work execution can lead to professional burnout of employees. All of this can result in stressful situations and cause the rejection or reluctance to work conscientiously. An employee can lose self-belief, begin to doubt about her or his professionalism and the correctness of choice of the place to work.

Mistakes in choosing the personnel for career promotion can also lead to professional burnout. Early promotion of the employee who is not yet ready to fulfillment of new responsibilities and to the new level of responsibility can result in failure of tasks and objectives realization, missed deadlines, mistaken decisions. Consequently, the employee experiences incompetence and frustration, which results in professional burnout.

For the prevention and control of professional burnout, company management needs to apply the achievements of stress management. A system of antistress motivation that allows minimizing the effects of stress on employees should be created. Thus it is necessary at the early stages to identify the factors of burnout and to take the following measures: to create a favorable working climate, to use a flexible system of stimulating and maintenance of interest to work, to diversify working conditions and employees rest. Such system should not be constant; otherwise, its effectiveness will decrease. It must be periodically updated and supplemented with new elements in order to stimulate the employees' desire to develop and promote.

The task of the stress management is to develop a constructive attitude to stressful situations. To eliminate the burnout, it is necessary to carry out stress prevention resulting from hypertension as well as boredom, apathy and fatigue. All these determine the necessity of constant team work on the formation of attitudes and values aimed to promote a healthy lifestyle and working activity [11].

\section{References}

1. C. Maslach, W.B. Schaufeli, M.P. Leiter, Annual Review of Psychology, 52, 397 (2001)

2. R.B. Kvesko, Ya.I. Chaplinskaya, S.A. Ishtunov, S.B. Kvesko, Fundamental and applied sciences today. 5th Conference on fundamental and applied sciences today, 3, 154 (2015)

3. J.B. MacDonald, A. J. Saliba, G. Hodgins, L. A. Ovington, Burnout Research, 3, 34 (2016)

4. H. Wang, N.C.Hall, S. Teaching and Teacher Education, 47, 120 (2015)

5. R. Martins, A. Andrade, C. Albuquerque, M. Cunha, Turkish Online Journal of Educational Technology 2015, 523 (2015)

6. S.F. Kelty, H. Gordon, Psychiatry, Psychology and Law, 22 (2), 273 (2015)

7. K. Kashani, P. Carrera, A.G. De Moraes, J.A. Onigkeit, K. Ramar, Medical Education, 20 (1), 27840 (2015) 
8. N. McCormack, C. Cotter, Burnout in the Workplace. A Guide for Information Professionals (Oxford Cambridge New Delhi, 2013)

9. M. Ronchetti, C. Di Tecco, S. Russo, B. Persechino, S. Iavicoli, Safety Science, 80, 310 (2015)

10. A. Harder, J. Gouldthorpe, J. Goodwin, Journal of Extension, 53 (2), 2FEA2 (2015)

11. R.B. Kvesko, S.B.Kvesko, Y.I. Chaplinskaya, Proceedings of the 2nd International Sciences Congress "Fundamental Studies in America, Europe and Asia: Humanitarian and Social Sciences". International Agency for Development of Culture, Education and Science ("Columbia Press". New York, 2014) 